\title{
Mottled Color of Placental Parenchyma
}

National Cancer Institute

\section{Source}

National Cancer Institute. Mottled Color of Placental Parenchyma. NCI Thesaurus. Code C117370.

The variable or non-uniform coloring of the placental parenchyma indicating variable contribution of the blood contained within the fetal vessels to the color of the parenchyma. 